$A^{S}$ a country Britain is living beyond its means, and it is surely no more than good sense to consider ways in which we can meet more of our needs from our own resources, among which agricultural resources figure prominently. In the past 100 years or so the latter have been evaluated against a background of abundant world supplies of food, available freely except for short periods of war and post-war restriction, and to be purchased cheaply in relation to the price of the industrial goods we had to offer in exchange. We have rarely had an explicitly formulated agricultural policy, but the de facto policy that has grown up has resulted from the impact of these world forces.

The world situation has changed, dramatically and to our disadvantage. Although agricultural production has increased enormously over the past quarter century, the increase has been taken up by population growth and by the increasing sophistication of the diets of affluent countries. Thus, now that the basic resources on which farm production depends-land, fertilisers and energy-have become scarce and costly, we have no margin to protect us against shortage; prices have risen greatly in rich countries, and poor countries face widespread hunger. In this context we should reappraise our agricultural assets, with a view to meeting from them more of our needs.

In Britain we enjoy a generous, not to say extravagant, diet, including a high proportion of animal products. The livestock industry has come to depend very heavily on concentrate feeding, and home feed production is augmented by massive imports of coarse grains and protein feedstuffs. In present circumstances this is a profligate way of feeding ourselves, and we know that we could devise a palatable and nutritionally adequate diet at much less expense in real resources, and with much less dependence on imports. A reduction in the heavy consumption of animal products would make a major contribution to Britain's balance of payments, and would help ease the world food situation.

The corresponding changes in the production pattern of British agriculture would require extensive planning, and would take some years to implement in full. It is, therefore, particularly important that we should start planning without delay. Planning of this order is beyond the time scale of political parties and exceeds the sectional interests of farming organisations. But it is vital if agriculture is to contribute more substantially to the solution of our economic problems. Some of the major topics to be considered in such an enterprise are out-

\title{
Agriculture and nutrition
}

\author{
Almost overnight the scientific community at large has discovered \\ of much more attention. Sir Joseph Hutchinson argues for a majo \\ (left). Professor Jean Tremolières points to the need to stimulate Fr
}

lined here, in the hope of encouraging interested people to get together, to study agricultural policy in depth, and to make known their conclusions.

- Cropping pattern. Cereals are the basic foodstuffs of the human race. In the British diet we consume approximately $90 \mathrm{~kg}$ a head a year directly, and use about $360 \mathrm{~kg}$ a head to feed to livestock which produce meat, milk and eggs. For this we grow 13-15 million tonnes and import 8-9 million tonnes. How would one implement a decision to (a) halve, or (b) eliminate cereal imports? This would fall under two heads; first, the replacement of imported cereals used in human food, chiefly by growing good milling instead of low quality winter wheats, and replacing some of the spring barley crop with good quality spring wheats; and, second, the reduction of cerealbased livestock production to match the reduction in the availability of feed grain. Of this we have the experience of the Second World War, when pig and poultry stocks were drastically cut back, and beef production was limited to the available grass feeding acreage.

Other crops would not be so directly affected. Potatoes would probably remain about as at present. There might be considerable debate about sugar beet, but considering the need of the Third World for access to industrial markets, and the disfavour with which sugar is regarded by nutritionists, it seems likely that the crop should be stabilised at a level appropriate to use as a rotation crop in arable farming.

In a diet with a lower meat content, vegetables might have a larger place, and vegetable crops might be increased. Oilseeds are almost entirely imported, and cilseed crops should be reviewed. Ley breaks in arable rotations would assume greater importance, and are considered in relation to the maintenance of fertility.

- Fertility levels. The present high fertility of British farm land has been achieved by the liberal, and at times almost profligate, use of fertilisers. Now that these have become expensive and scarce, there is no doubt that considerable savings can be made by more discriminating fertiliser practice. Greater savings are to be gained by better distribution of animal manure, and by the use of leguminous crops to augment the nitrogen supply. These two are interrelated, since the tendency to separate crop production from animal industry has resulted in an inconvenient concentration of animal manure on livestock farms and an abandonment of grass/legume leys on arable farms.

The redistribution of crops and stock in order to maximise the conservation of fertility would be the most important and the most difficult consequence of this kind of reappraisal of British agriculture. The rundown of intensive livestock enterprises would involve writing off capital in intensive housing, and the reintroduction of grazing livestock on intensive arable farms would require investment in fencing, water supply and some winter housing. How much? At what rate? And where?

- Human nutrition. Human nutrition lags behind animal nutrition on account of the difficulties of experimentation with human subjects. The diversity of opinion among eminent nutritionists as to the causes of the 'diseases of affluence' is sufficient indication of the uncertainties of the subject. Nevertheless, the existence of diseases associated with affluence is not in dispute, and this, together with economic need and the limitations of world food supply, is a powerful reason for devising diets that are less demanding on resources, and perhaps less menacing to health.

In conclusion, these are three major areas in which we have substantial room to manoeuvre. If we are to exploit the freedom of choice open to us with a view to realising the fullest potential of our agricultural resources, some of us must get down to the hard work of studying these topics, and charting a course of action in detail. Some groups are already concerned in this area, notably the Joint Consultative Organisation recently set up by the Ministry of Agriculture, Fisheries and Food to give guidance on research priorities, but we need a wider assessment of the place of British agriculture in British economic policy. Are we interested to provide a factual basis on which informed opinion can be built, or are we content to stumble from Price Review to Common Agricultural Policy negotiation without real understanding of where we are going? 